\title{
Investigating Factors Affecting the Adoption of Renewable Energy within Businesses in the Egyptian Market: An Exploratory Research
}

\author{
Sayed Sharaf \\ Assistant Lecturer at the Business Administration Department \\ Cairo University, P.O, Box 12631, Egypt \\ E-mail: sayedkamal@foc.cu.edu.eg \\ Wael Kortam \\ Professor of Marketing \\ Business Administration Department \\ Cairo University, P.O, Box 12631, Egypt \\ E-mail:wael.kortam@foc.cu.edu.eg
}

Received: December 10, 2019 Accepted: January 20, $2020 \quad$ Published: March 28, 2020

doi:10.5296/wjbm.v6i1.16017ＵRL: https://doi.org/10.5296/wjbm.v6i1.16017

\begin{abstract}
This paper aims at discovering a suitable theory for understanding the adoption of renewable energy (RE) among investors and decision-makers in the Egyptian market as well as disclosing the research gaps related to examining the drivers that affect spreading RE sources in the various societies. Finally, it will explore the factors that influence the adoption of RE in different organizations to increase the diffusion of RE inside the Egyptian society. Therefore, it is important to understand how business customers select the type of energy whether conventional energy or RE or mixed. Hence, this study examines the drivers that influence business customers' choices of RE versus conventional energy for pushing toward adopting the RE investment inside the firms. Exploratory research is used in this investigation; therefore, data for this study is collected using literature reviews, international and local reports, in addition to unstructured interviews with potential and actual customers as well as practitioners and academics in the RE sector. This study will benefit Egyptian policymakers and $\mathrm{RE}$ companies in the marketing of RE sources through understanding the drivers of adopting RE within businesses.
\end{abstract}


Keywords: Theories and models of adopting RE, Diffusion of innovation theory, Business customers, Factors of adopting RE, The position of RE sector in the Egyptian market 


\section{Introduction}

In recent years, RE has become the world's strategic choice to solve environmental pollution, handle the energy crisis and achieve sustainable development. Renewable energy (RE), refers to the energy that is produced by utilizing the natural resources that are continuously replenished and never run out such as solar energy, wind energy, bioenergy, hydropower energy, and so on (Australian Renewable Energy Agency, 2019; Wang, O’Donnell, \& Brandt, 2017; Zhao, Noori, \& Tatari, 2017). Due to the RE adoption, investment within businesses may play a significant role toward improving business performance through decreasing electricity costs that can be avoided in the long run and gaining other competitive advantages (Aladassy, Mosaad, \& Tarabieh, 2016; OECD/IEA and IRENA, 2017). The institutions are increasingly being promoted encouraged to adopt RE sources instead of traditional energy by governments and RE companies. It may lead Egyptian economic growth to be enhanced through reducing Egypt's budget deficit, decreasing importing traditional energy sources, helping to reduce the unemployment rate, and reaching low carbon economy (Lehr \& Hegazi, 2017; Sharaf, 2016).

This paper observed that the percentage of RE usage within business customers is low compared to their consumption of electricity which reached $41 \%$, it may indicate that business customers are less enthusiastic to adopt RE (Arabic Egyptian Electricity Holding Company, 2016). Additionally, this study makes the main contribution to the prior studies of RE diffusion and contributes to achieve the strategic goal that was recommended by the World Bank and Egypt's vision 2030, which stated that RE should reach 35\% or more and become the highest source for electricity generated in 2030 in the Egyptian market (Ministry of Planning, Monitoring and Administrative Reform, 2017; World Bank, 2017). Moreover, the findings indicate the most critical factors to improve the support to investors and decision- makers to increase adoption of RE investment.

\section{Theories and Models of Interpreting Adoption of RE}

In all the studies reviewed, there are the theories and models that interpreted the adoption phenomenon, but this study is designed to address the theories and models that have been utilized to understand how to adopt RE sources, as can be seen in Table 1.

For further details, Reyes-Mercado (2017) integrated the diffusion of innovation theory with cognitive frameworks for determining the factors that influence the adoption of solar energy technologies for urban households in Mexico (Reyes-Mercado, 2017). Similarly, Alam (2014) suggested a research model in accordance with the diffusion of innovation theory and the other theories that enhanced our perception of customer preferences toward RE use in Malaysia (Alam et al., 2014). As a result, the diffusion of innovation theory (DOI) can contribute to interpreting how, why, and at the rate of RE diffusion. Additionally, providing mechanisms for the communication of new ideas such as efficiency energy and RE use in the social system and proposing a set of attributes that construe the customer's decision of adopting RE (Mani \& Dhingra, 2012; Rogers, 1995, 2003; Sharma \& Mishra, 2014). 
Table 1. Theories and models that used for explaining the adoption of RE

\begin{tabular}{|c|c|c|}
\hline Theory / Model & $\begin{array}{c}\text { Constructs / Determinants of } \\
\text { adoption }\end{array}$ & $\begin{array}{c}\text { Studies applied theories for } \\
\text { adopting RE }\end{array}$ \\
\hline $\begin{array}{l}\text { Diffusion of Innovation } \\
\text { Theory (DOI) }\end{array}$ & $\begin{array}{l}\text { The innovation, communication, time } \\
\text { and social system }\end{array}$ & $\begin{array}{c}\text { (Reyes-Mercado, 2017) } \\
\text { (Alam et al., 2014) } \\
\text { (Lin \& Huang, 2012) }\end{array}$ \\
\hline $\begin{array}{l}\text { Theory of Customer } \\
\text { Value }\end{array}$ & $\begin{array}{l}\text { Focuses on the comparison between } \\
\text { the benefits and sacrifices by } \\
\text { customers (individuals or } \\
\text { organizations) }\end{array}$ & $\begin{array}{l}\text { (Sangroya \& Nayak, 2017) } \\
\text { (Papista \& Krystallis, 2013) }\end{array}$ \\
\hline $\begin{array}{c}\text { Theory of Reasoned } \\
\text { Action (TRA) }\end{array}$ & $\begin{array}{l}\text { Behavioral intention, attitude and } \\
\text { subjective norms }\end{array}$ & $\begin{array}{c}\text { (Zahari \& Esa, 2016) } \\
\text { (Ha \& Janda, 2012) }\end{array}$ \\
\hline $\begin{array}{c}\text { Theory of Planned } \\
\text { Behavior (TPB) }\end{array}$ & $\begin{array}{c}\text { Behavioral intention, attitude, } \\
\text { subjective norms and perceived } \\
\text { behavioral control }\end{array}$ & $\begin{array}{l}\text { (Park \& Ohm, 2014) } \\
\text { (Yun \& Lee, 2015) }\end{array}$ \\
\hline $\begin{array}{l}\text { Behavioral Reasoning } \\
\text { Theory (BRT) }\end{array}$ & $\begin{array}{l}\text { Behavioral intention, attitude, } \\
\text { subjective norms, perceived } \\
\text { behavioral control and } \\
\text { context-specific reasons } \\
\end{array}$ & $\begin{array}{l}\text { (Claudy, Peterson, \& } \\
\text { O’Driscoll, 2013) }\end{array}$ \\
\hline $\begin{array}{c}\text { Multi-level } \\
\text { socio-technical } \\
\text { Perspective (MLP) }\end{array}$ & $\begin{array}{l}\text { Explains the dynamics between } \\
\text { technology, norms, institutions, } \\
\text { markets and society }\end{array}$ & $\begin{array}{c}\text { (Sutherland, Peter \& Zagata, } \\
\text { 2015) } \\
\text { (Osunmuyiwa \& Kalfagianni, } \\
\text { 2017) }\end{array}$ \\
\hline $\begin{array}{l}\text { Technology Adoption } \\
\text { Model (TAM) }\end{array}$ & $\begin{array}{l}\text { Perceived usefulness and Perceived } \\
\text { ease of use }\end{array}$ & $\begin{array}{l}\text { (Sharma \& Mishra, 2014) } \\
\text { (Viardot, 2013) }\end{array}$ \\
\hline $\begin{array}{l}\text { The Information-deficit } \\
\text { Model }\end{array}$ & $\begin{array}{l}\text { Interprets public understanding of } \\
\text { science (PUS), which is interested in } \\
\text { the connection between scientific } \\
\text { knowledge in general and science and } \\
\text { technology general perspectives }\end{array}$ & (Bidwell, 2016) \\
\hline
\end{tabular}

Source: Prepared by the researcher.

By contrast, Sangroya and Nayak (2017) used the theory of customer value to identify the factors that improve industrial green energy consumers relationship by investigating the impact of various dimensions of customer value on perceived switching costs in the industrial green energy market (Sangroya \& Nayak, 2017). Similarly, Papista and Krystallis (2013) propose an integrated model of customer value in the green marketing context to help give a better understanding of customer behavior toward green brands by utilizing the theory of customer value (Papista \& Krystallis, 2013). Accordingly, the customer value theory represents the main core in both management and marketing theory and practice. Generally, 
there is an agreement regarding the definition of customer value, which points out the comparison among the gains and sacrifices of getting products through customers (Graf \& Maas, 2008; Keränen \& Jalkala, 2014; Sun \& Su, 2012).

In contrast, Ha and Janda (2012) used the theory of reasoned action (TRA), and discovered that attitudes toward purchase energy-efficient products have a stronger effect on behavioral intentions compared to the subjective norms (Ha \& Janda, 2012). Similarly, Zahari and Esa (2016) employed the theory of reasoned action (TRA) to recognize the drivers motivating the adoption of $\mathrm{RE}$, as the results demonstrated that environmental concerns and relative advantages have more impact than consumer belief and consumer knowledge in the adoption of RE. As a result, the theory of reasoned action (TRA) declared that the prediction of intentions to implement a certain behavior depends on subjective norms and attitudes toward the behavior (Hai, Moula, \& Seppälä, 2017).

On the other hand, Yun and Lee (2015) aimed to investigate the effect of attitudes, perceived behavioral control and subjective norms on consumer's intentions toward RE systems by using the theory of planned behavior (TPB) (Yun \& Lee, 2015). Accordingly, TPB was developed through adding dimensions of Perceived Behavioral Control (PBC) to dimensions of the theory of reasoned action (TRA) (Hai et al., 2017; Sharma \& Mishra, 2014; Yun \& Lee, 2015). Conversely, Claudy et al. (2013) employed Behavioral Reasoning Theory (BRT) in an attempt to realize how consumers think regarding adopting RE. Hence, it included mediating dimensions such as reasons for or against adoption, and attitudes toward RE technology (Claudy et al., 2013). Commonly, behavioral reasoning theory gives a better understanding of consumer decision-making, because it presented a new dimension regarding context-specific reasons to the dimensions of the theory of planned behavior (Peattie, 2010; Westaby, Probst, $\&$ Lee, 2010).

Depending on the multi-level socio-technical theory, which aims at analyzing changes and stability in socio-technical systems, Sutherland et al. (2015) illustrated the importance of the agriculture sector for adopting RE through the agricultural policy. It can provide more opportunities for moving toward RE and affect many agricultural functions for adopting RE sources, for example, utilizing solar energy in the irrigation process instead of conventional energy. Accordingly, it is recommended that more interest should be paid to the impact of regime policies such as the agricultural policy on moving to RE use (Sutherland et al., 2015).

Moreover, Viardot (2013) applied the technology adoption model (TAM) to determine the various challenges of adopting RE and how to overcome those barriers to increase RE use (Viardot, 2013). As a result of technology adoption model (TAM), it aims at predicting the extent of adoption of new technology at an individual level (Sharma \& Mishra, 2014). Eventually, Bidwell (2016) employed the information-deficit model, as it was discovered that the involvement in the information events contributes to changes in attitudes toward wind energy greatly (Bidwell, 2016). As a result of the information deficit model (IDM), it aims at explaining the public understanding of science (PUS) through interest in the connection between scientific knowledge in general and science and technology general perspectives. It is also called the knowledge gap model, the deficit model and knowledge deficit model (Bidwell, 2016; McDivitt, 2016). 


\section{Drivers of Adopting Renewable Energy (RE)}

Despite growing articulated preferences for green products and environmental awareness, there are still slow rates of diffusion of sustainable energies. Recent trends toward sustainability issues have led to a proliferation of studies that demonstrated an increased interest in investigating many drivers, which may influence the RE diffusion in different organizations as indicated in Table 2. In the same vein, Claudy et al. (2013) recommended that more interest should be paid toward identifying attitudes, the reasons for or against adoption toward RE technology (Claudy et al., 2013).

In this context, some writers have attempted to divide the factors of adopting RE into two groups: In the first group are direct factors such as attitudes, subjective norms, perceived behavioral control and perceived cost. In the second group are indirect factors such as perceived social trust, perceived social support, perceived system quality, facilitating technical conditions, perceived trust, perceived benefits, knowledge and perceived risks (Park \& Ohm, 2014; Yun \& Lee, 2015). According to Noppers et al. (2016), they concluded that the symbolic attributes of sustainable innovations are improved and stressed by the policy, which took into consideration the symbolic attributes to boost the adoption of sustainable innovations. In addition, this study found that actual adoption of smart energy systems is explained by the symbolic attributes more than the other variables; they are instrumental attributes and environmental attributes (Noppers, Keizer, Milovanovic, \& Steg, 2016).

In contrast, the findings by Sangroya and Nayak (2017) demonstrated clearly that customer loyalty toward green energy is affected through the impact of the dimensions of customer value (conditional value, functional value, social value, and emotional value) on perceived switching cost. In addition, conditional value has the biggest effect compare to the other dimensions of customer value for developing loyalty of industrial customers toward green energy (Sangroya \& Nayak, 2017).

Furthermore, a willingness to pay (WTP) plays a key role in determining the level of RE acceptance, WTP can be estimated by using the contingent valuation (CV) method, which is most commonly applied to analyze consumer's preferences. For instance, employing the contingent valuation (CV) method for measuring Korean consumers' additional WTP toward RE sources. The results of WTP estimation indicated that policies could affect WTP through targeting the advancement of knowledge and acceptance of RE sources among Korean consumers who are characterized by low WTP comparative to other advanced nations (C.-Y. Lee \& Heo, 2016). In this regard, the behavioral intentions toward the use of solar energy have been formed by willingness to pay, to change and to invest (Baharoon, Rahman, \& Fadhl, 2016). As noted also by Baharoon et al (2016) there is a difference between the public's knowledge and attitudes toward the use of solar energy among urban and rural areas as a result of the factor of residence place (Baharoon et al., 2016). 
Table 2. The factors influence moving toward RE adoption

\begin{tabular}{|c|c|c|c|}
\hline Study & The factors of adopting $\mathrm{RE}$ & Customers & Country \\
\hline $\begin{array}{l}\text { (Sangroya \& } \\
\text { Nayak, 2017) }\end{array}$ & $\begin{array}{l}\text { - Functional value points out the perceived utility of a product by a capacity } \\
\text { to execute its functions. } \\
\text { - Social value means findings from the social perception of the products } \\
\text { purchase and consumption by a customer in surrounding environment. } \\
\text { - Emotional value refers to the emotions and feelings that a purchaser attaches } \\
\text { to the product. } \\
\text { - Conditional value, namely a utility that is drawn from a given situation such } \\
\text { as government offer of subsidies. }\end{array}$ & Industrial Consumers & India \\
\hline $\begin{array}{l}\text { (Noppers, Keizer, } \\
\text { Milovanovic, \& } \\
\text { Steg, 2016) }\end{array}$ & $\begin{array}{l}\text { - Instrumental attributes, namely the utility of utilizing a sustainable } \\
\text { innovation. } \\
\text { - Environmental attributes refer to the outcomes of utilizing a sustainable } \\
\text { innovation for environmental quality. } \\
\text { - Symbolic attributes mean the impacts of utilizing sustainable innovations on } \\
\text { one's social status and self-identity. }\end{array}$ & Households & Netherlands \\
\hline (Lee \& Heo, 2016) & $\begin{array}{l}\text { - Estimates willingness to pay (WTP) for using various sources of RE. } \\
\text { - RE policies can influence willingness to pay (WTP) through enhancing } \\
\text { lnowledge and acceptance of RE sources. }\end{array}$ & Korean consumers & South Korea \\
\hline (Bidwell, 2016) & $\begin{array}{l}\text { - Providing information to the members of the public. } \\
\text { - Participation in an information session. }\end{array}$ & $\begin{array}{l}\text { The residents of coastal } \\
\text { communities in Michigan }\end{array}$ & United States \\
\hline $\begin{array}{l}\text { (Fergen \& B. } \\
\text { Jacquet, 2016) }\end{array}$ & $\begin{array}{l}\text { - Expectations of wind farm } \\
\text { Economic and environmental value }\end{array}$ & $\begin{array}{l}\text { The rural residents in the } \\
\text { state of South Dakota (SD). }\end{array}$ & United States \\
\hline
\end{tabular}

\begin{tabular}{|c|c|c|c|c|}
\hline Study & \multicolumn{2}{|c|}{ The factors of adopting $R E$} & Customers & Country \\
\hline $\begin{array}{l}\text { (Zahari \& Esa, } \\
\text { 2016) }\end{array}$ & $\begin{array}{l}\text { - Environmental concern } \\
\text { - Consumer knowledge }\end{array}$ & $\begin{array}{l}\text { - Consumer beliefs } \\
\text { - Relative advantage }\end{array}$ & $\begin{array}{l}\text { The undergraduates are } \\
\text { from one of the business } \\
\text { schools in one of the } \\
\text { Government-Linked } \\
\text { University (GLU) }\end{array}$ & Malaysia \\
\hline $\begin{array}{l}\text { (Baharoon, } \\
\text { Rahman, \& } \\
\text { Fadhl, 2016) }\end{array}$ & $\begin{array}{l}\text { - Public's knowledge } \\
\text { - Public's attitudes }\end{array}$ & $\begin{array}{l}\text { - Personal observation and experience } \\
\text { - Public's behavioral intentions }\end{array}$ & Households & Yemen \\
\hline $\begin{array}{l}\text { (Yun \& Lee, } \\
\text { 2015) }\end{array}$ & $\begin{array}{l}\text { - Direct factors: "attitude } \\
\text { - Indirect factors: "perce } \\
\text { system quality - facilita }\end{array}$ & $\begin{array}{l}\text { - subjective norms - perceived behavioral control" } \\
\text { ived social trust - perceived social support - perceived } \\
\text { ting technical conditions" }\end{array}$ & $\begin{array}{l}\text { The residents of West } \\
\text { and Midwest regions }\end{array}$ & United States \\
\hline $\begin{array}{l}\text { (Park \& Ohm, } \\
\text { 2014) }\end{array}$ & $\begin{array}{l}\text { - Indirect factors: "perc } \\
\text { perceived risks" } \\
\text { - Direct factors: "public a }\end{array}$ & $\begin{array}{l}\text { eived trust - perceived benefits - knowledge - } \\
\text { sttitude - perceived cost" }\end{array}$ & $\begin{array}{l}\text { The residents of six } \\
\text { regions and } 18 \text { cities. }\end{array}$ & South Korea \\
\hline $\begin{array}{c}\text { (Alam et al., } \\
2014 \text { ) }\end{array}$ & $\begin{array}{l}\text { - Relative advantage } \\
\text { - Awareness }\end{array}$ & $\begin{array}{l}\text { - Cost } \quad \text { - Perceived ease of use } \\
\text { - Perceived behavioral control }\end{array}$ & $\begin{array}{l}\text { Malaysian urban } \\
\text { residents }\end{array}$ & Malaysia \\
\hline $\begin{array}{c}\text { (Zyadin, } \\
\text { Puhakka, } \\
\text { Ahponen, \& } \\
\text { Pelkonen, 2014) }\end{array}$ & $\begin{array}{l}\text { - General RE knowledge } \\
\text { - Personal attitudes }\end{array}$ & - Perceptions of RE implementation & $\begin{array}{l}\text { Secondary school } \\
\text { teachers }\end{array}$ & Jordan \\
\hline
\end{tabular}

Source: Prepared by the researcher.

Few authors have mainly highlighted the relevance of the general customer knowledge and awareness regarding RE, for example, RE sources, benefits, drawbacks, technologies and so on. Meanwhile, these studies have claimed that more interest should be paid to RE knowledge and awareness by providing formal and informal education, giving information to the stakeholders and public members and encouraging the participation in an information session (Alam et al., 2014; Baharoon et al., 2016; Bidwell, 2016; Zahari \& Esa, 2016; Zyadin, 
Puhakka, Ahponen, \& Pelkonen, 2014). Additionally, there are some researchers who have focused on investigation regarding the role of attitudes as one of RE critical factors, for instance, personal and public attitudes for changing attitudes toward RE use instead of conventional energy (Baharoon et al., 2016; Park \& Ohm, 2014; Yun \& Lee, 2015; Zyadin et al., 2014).

Similarly, RE benefits have been highlighted by some writers such as examining relative advantages relative to traditional energy, investigating the degree of expected advantages satisfactions and displaying more benefits related to applying RE (Fergen \& B. Jacquet, 2016; Ferreira et al., 2018; Ito, 2017; Zahari \& Esa, 2016). Moreover, there are other drivers associated with the use of RE as have been demonstrated by some studies such as environmental concern, consumer beliefs, perceptions of RE implementation, cost and perceived ease of use (Alam et al., 2014; Zahari \& Esa, 2016; Zyadin et al., 2014).

\section{The Nature of RE Sector in the Egyptian Market}

There is no doubt that a few developing countries have achieved a sharp jump in RE investments rates over the last period, especially since the beginning of 2015 such as Egypt, Jordan and Kenya. For example, RE investments have leapt pointedly from zero in 2015 to almost \$ 700 million in 2016 in Egypt (McCrone, Moslener, D’Estais, \& Grünig, 2017; REN21 Renewable Energy Policy Network for 21st Century, 2017). It may be due to the Egyptian government launch of several procedures and policies of RE to push organizations and households toward using one of the RE sources. For instance, permitting private electricity plants (for example, Solar energy plant) to be connected with the public grid (On-grid system), allowing the installation of separated private electricity plant from the utility grid (Off-grid system), launching net metering policy, which refers to the customer right regarding selling surplus electricity from the private electricity plant to government as well as granting the right of renting the public grid for transmitting generated electricity from private electricity plant to consumed places of electricity, and this policy is called "Independent power producer (IPP)" (BloombergNEF, 2018; Kotb, 2018; New \& Renewable Energy Authority, 2018; Regional Center for Renewable Energy and Energy Efficiency (RCREEE), 2013; TSAGAS, 2017).

Furthermore, the Egyptian government targeted the decline of electricity subsidies, notably the energy-intensive industries and households for five years (2014-2019) (World Bank, 2017). For this reason, it may lead companies to lose their competitive advantage of pricing because of rising electricity costs. These findings may contribute to reduce revenues and increase costs of businesses, such as decreasing revenues of hotels for more than roughly $20 \%$ in 2014 (Aladassy et al., 2016). Additionally, firms may not accept the instability of electricity costs and disruption to electricity supply from time to time. Thus, they may accept a high initial investment of transition toward RE to avoid electricity costs in the long run. Conversely, the Egyptian customer fully depends on the government to provide electricity and may accept disruption to the electricity supply now and then and electricity costs, besides an inability or lack of desire to afford high initial costs of moving toward clean energy (Aladassy et al., 2016; McCrone et al., 2017; OECD/IEA and IRENA, 2017; World bank, 2017). 


\section{Macrothink Institute ${ }^{T M}$}

Consequently, some companies have been forced to adopt efficiency energy policies in their activities to save electricity, while there are a number of companies that owned private electricity plant by using one of RE sources. Despite the policies and procedures that have been implemented by the Egyptian government to encourage companies and households to use RE sources, there are few firms that have adopted RE as their electricity source. More clearly, the percentage of solar and wind energy has never exceeded $2.1 \%$ of the total of electrical energy production, whereas -as demonstrated in Figure 1 - that the consumption percentage of the industrial, agricultural and commercial sectors have reached roughly $41.1 \%$ of the total of electrical energy consumption (Arabic Egyptian Electricity Holding Company, 2016; Egyptian Electricity Holding Co, 2018). According to Solar Atlas that Egypt is rich in solar radiation annually. In addition, solar energy technology is available in the Egyptian market, as RE companies that provide services of installation, maintenance, supply of components (for example, solar cell, solar inverter, solar battery...) have reached more than 220 firms in the Egyptian market (Kosmopoulos, El-Askary, \& Kazadzis, 2018; New \& Renewable Energy Authority, 2018).

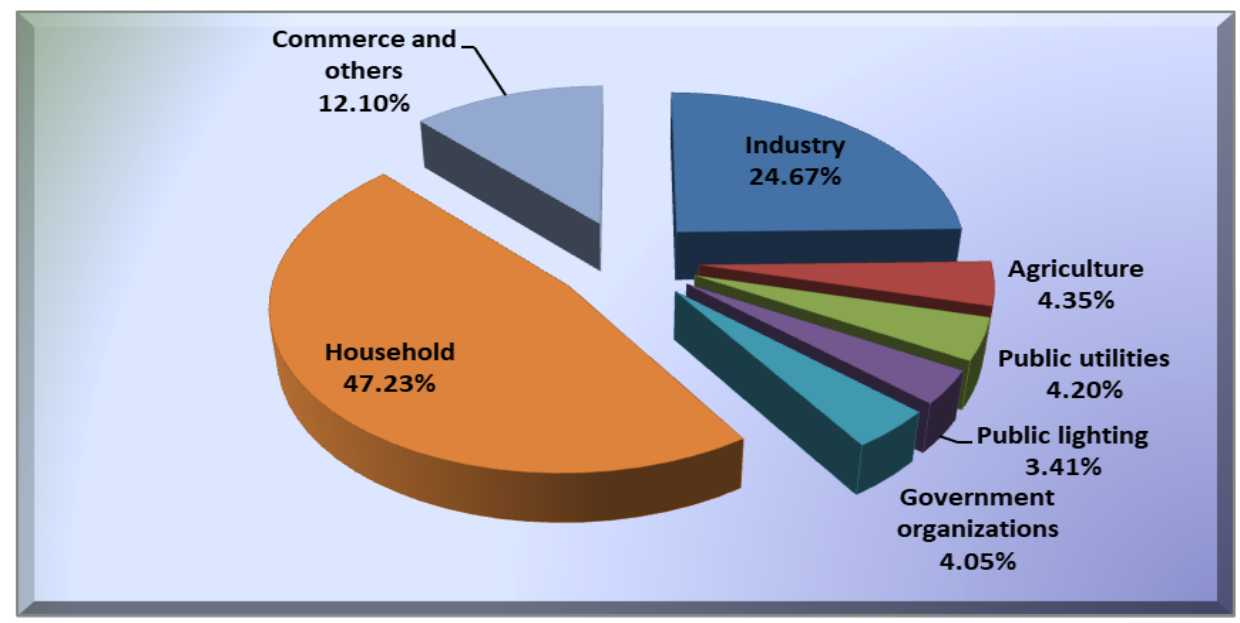

Figure 1. Distribution of electricity energy consumption for different purposes (2015/2016)

Source: Depending on Data from Arabic Egyptian Electricity Holding Company, 2016.

\section{Research Design}

The exploratory research was applied in this paper to understand how investors and decision-makers view the adoption of RE by exploring the factors that may influence the decision to adopt one of the RE sources in their organizations. Drawing on 1) theories and models used for explaining the adoption of RE in a literature review, 2) the drivers of adopting RE have been presented in the prior studies, 3) international and local reports have displayed the position of RE in the Egyptian market.

Eventually, the unstructured interviews were conducted by meeting some potential and actual business customers (investors and decision-makers), beside practitioners and academics in the RE sector, as the number of interviewees has reached 23 participants, whether face to face 
meeting or online meeting (Saunders, Lewis, \& Thornhill, 2016; Zikmund, Babin, Carr, \& Griffin, 2009).

\section{Conclusions and Recommendations}

Overall, the findings of this paper demonstrate that the diffusion theory of innovations (DOI) is suitable to explain how RE can be diffused as a new product in the Egyptian community, because RE is considered in the first phase of the product life cycle (Rogers, 2003; World Bank, 2017). Furthermore, the Egyptian market needs both behavior and social change of decision-makers and investors toward the RE issue. Accordingly, DOI focuses on both social and behavior change, whereas most theories seek toward behavior change only (Rogers, 2003; Sharma \& Mishra, 2014; World Bank, 2017). Moreover, investors and decision-makers are more likely to favor investments of the new ideas or issues like clean energy issue, as illustrated that DOI explains the behavior of adopters toward innovations such as innovators and early adopters (Y. Lee, Wang, Kao, Chen, \& Zhu., 2010; Rogers, 2003). Additionally, Knowledge, community support and trustworthy communication channels are central elements to spread RE, as DOI demonstrated the significance of communication channels, knowledge and community support concerning the adoption of innovation (Dinica, 2006; Gatzert \& Vogl, 2016; KPMG, 2017; Rogers, 2003). Meanwhile, DOI has been taking into consideration various aspects such as technological, social and behavioral dimensions that may affect the adoption of RE (Alam et al., 2014; Mani \& Dhingra, 2012; Reyes-Mercado, 2017).

Generally, this research has observed that the emerging markets have never received more attention from researchers compared to developed markets, notably the countries, which have never been oil-rich, also characterized by a less developed economy, and less advanced industry. Meanwhile, they own at least one of the RE sources, in abundance such as the Egyptian market that possesses strong solar energy over the year, as well as being able to recycle the available waste continuously to generate electricity through applying bioenergy technology (Abdelhady, Borello, \& Shaban, 2017; Atalay, Biermann, \& Kalfagianni, 2016). Despite the importance of the role of investors and decision-makers for growing the diffusion of using RE in the various sectors, most studies have concentrated on the view of customers like households. At the same time, there has been little interest in the role of the commerce exchange between RE companies and the other firms for spreading RE in the societies by providing RE goods and services to the different organizations. Business-to-Business (B2B) can contribute to diffuse RE greatly in the Egyptian market (Claudy et al., 2013; Sangroya \& Nayak, 2017; Uzialko, 2017). For instance, encouraging the real estate developers to adopt the solar energy in their projects, can lead to an increased acceptance of RE among customers.

Finally, the drivers found likely to be influencing the adoption of RE within businesses in the Egyptian market have been explored via this study. In the following, RE relative advantages should be maximized comparative to traditional energy such as the benefits of social, investment, marketing, environment and so on (Alam et al., 2014; Rogers, 2003). Hence, RE benefits should never be confined to the financial benefits as observed in the Egyptian market. Additionally, the social trust of investors and decision-makers regarding RE use inside their 
organizations must be increased, as customers depend on specialized institutions in the case of adopting new technology such as RE technology when they have not enough knowledge (Yun \& Lee, 2015). Therefore, the specialized institutions (for example, universities, research agencies and so on) should provide support to business customers by giving training, educational courses and consultants of RE aspects.

Accordingly, social community support surrounding investors and decision-makers is an important factor. Business customers will usually realize the importance of RE diffusion when a surrounding environment is supportive of the RE use and provides more knowledge about it (Yun \& Lee, 2015). Thus, the specialized discussions must be organized concerning the RE benefits inside businesses by conducting meetings in such federations of industries, trade and industrial exhibitions, commerce chambers, business associations, and so on. In addition, knowledge and awareness are considered critical factors behind the adoption of RE within the Egyptian society. Consequently, it is necessary to boost the initiatives to raise awareness and improve the knowledge of RE investments opportunities by providing training, conferences, education, workshops, exhibitions and so on (Baharoon et al., 2016).

Furthermore, RE costs play an essential role in the decision to adopt RE instead of traditional energy inside businesses. Willingness to pay by business customers must be increased by maximizing the value of RE investment, as it has become almost equal to the RE costs, in which the RE adoption should influence positively on branding, organization performance and so on. Additionally, it is important to decrease the financial costs of RE use, particularly the initial costs of RE and reducing the non-financial costs such as opportunity cost, structural cost and so on (Donovan \& Henley, 2010; Lee \& Heo, 2016).

\section{References}

Abdelhady, S., Borello, D., \& Shaban, A. (2017). Assessment of levelized cost of electricity of offshore wind energy in Egypt. Wind Engineering, 41(3), 160-173. https://doi.org/10.1177/0309524X17706846

Aladassy, A., Mosaad, G., \& Tarabieh, K. (2016). Towards optimum energy performance measures for existing hotels in Egypt. Sustainable Tourisim, VII, 201(St). https://doi.org/10.2495/st160161

Alam, S. S., Nik Hashim, N. H., Rashid, M., Omar, N. A., Ahsan, N., \& Ismail, M. D. (2014). Small-scale households renewable energy usage intention: Theoretical development and empirical settings. Renewable Energy, 68, 255-263. https://doi.org/10.1016/j.renene.2014.02.010

Arabic Egyptian Electricity Holding Company. (2016). Arabic Egyptian Electricity Holding Company Annaul Report 2015-2016.

Atalay, Y., Biermann, F., \& Kalfagianni, A. (2016). Adoption of renewable energy technologies in oil-rich countries: Explaining policy variation in the Gulf Cooperation Council states. Renewable Energy, 85, 206-214. https://doi.org/10.1016/j.renene.2015.06.045

Australian Renewable Energy Agency. (2019). What is renewable energy? Retrieved 
September 20, 2009, from https://arena.gov.au/renewable-energy-technologies/

Baharoon, D. A., Rahman, H. A., \& Fadhl, S. O. (2016). Publics' knowledge, attitudes and behavioral toward the use of solar energy in Yemen power sector. Renewable and Sustainable Energy Reviews, 60, 498-515. https://doi.org/10.1016/j.rser.2015.12.110

Bidwell, D. (2016). The Effects of Information on Public Attitudes Toward Renewable Energy. Environment and Behavior, (Vol. 48). https://doi.org/10.1177/0013916514554696

BloombergNEF. (2018). EGYPT NET METERING. Retrieved from http://global-climatescope.org/en/policies/\#/policy/5056

Claudy, M. C., Peterson, M., \& O'Driscoll, A. (2013). Understanding the Attitude-Behavior Gap for Renewable Energy Systems Using Behavioral Reasoning Theory. Journal of Macromarketing, 33(4), 273-287. https://doi.org/10.1177/0276146713481605

Dinica, V. (2006). Support systems for the diffusion of renewable energy technologies - An investor perspective. Energy Policy, 34(4), 461-480. https://doi.org/10.1016/j.enpol.2004.06.014

Donovan, R., \& Henley, N. (2010). Principles and Practice of social marketing: An international perspective. Cambridge University Press. https://doi.org/10.1017/CBO9780511761751

Egyptian Electricity Holding Co. (2018). Annual Report - The Egyptian Electricity Holding company. Retrieved from http://www.eehc.gov.eg/eehcportal/YearlyReport/finalarabic.pdf

Fergen, J., \& B. Jacquet, J. (2016). Beauty in motion: Expectations, attitudes, and values of wind energy development in the rural U.S. Energy Research and Social Science, 11, 133-141. https://doi.org/10.1016/j.erss.2015.09.003

Ferreira, A., Kunh, S. S., Fagnani, K. C., De Souza, T. A., Tonezer, C., Dos Santos, G. R., \& Coimbra-Araújo, C. H. (2018). Economic overview of the use and production of photovoltaic solar energy in brazil. Renewable and Sustainable Energy Reviews, 81(April 2016), 181-191. https://doi.org/10.1016/j.rser.2017.06.102

Graf, A., \& Maas, P. (2008). Customer value from a customer perspective: A comprehensive review. Journal Für Betriebswirtschaft, $\quad 58(1), \quad$ 1-20. https://doi.org/10.1007/s11301-008-0032-8

Ha, H. Y., \& Janda, S. (2012). Predicting consumer intentions to purchase energy-efficient products April. The Journal of Consumer Marketing, 29(7), 461-469. https://doi.org/http://dx.doi.org/10.1108/07363761211274974

Hai, M. A., Moula, M. M. E., \& Seppälä, U. (2017). Results of intention-behaviour gap for solar energy in regular residential buildings in Finland. International Journal of Sustainable Built Environment. https://doi.org/10.1016/j.ijsbe.2017.04.002

Ito, K. (2017). CO2 emissions, renewable and non-renewable energy consumption, and economic growth: Evidence from panel data for developing countries. International 
Economics, 151(February), 1-6. https://doi.org/10.1016/j.inteco.2017.02.001

Jh, bGatzert, N., \& Vogl, N. (2016). Evaluating investments in renewable energy under policy risks. Energy Policy, 95, 238-252. https://doi.org/10.1016/j.enpol.2016.04.027

Keränen, J., \& Jalkala, A. (2014). Three strategies for customer value assessment in business markets. Management Decision, 52(1), 79-100. https://doi.org/10.1108/MD-04-2013-0230

Kosmopoulos, P., El-Askary, H., \& Kazadzis, S. (2018). THE SOLAR ATLAS OF EGYPT. Retrieved from http://www.nrea.gov.eg/Content/files/SOLAR ATLAS 2018 digital1.pdf

Kotb, A. (2018). Powering Egypt: More solar solutions. Retrieved from http://english.ahram.org.eg/NewsContent/3/12/286651/Business/Economy/Powering-EgyptMore-solar-solutions.aspx

KPMG, S. T. (2017). Renewable energy in Egypt. KPMG, (February). Retrieved from www.kpmg.com/uk

Lee, C. Y., \& Heo, H. (2016). Estimating willingness to pay for renewable energy in South Korea using the contingent valuation method. Energy Policy, 94, 150-156. https://doi.org/10.1016/j.enpol.2016.03.051

Lee, Y., Wang, G.-L., Kao, K.-S., Chen, C.-Y., \& Zhu, F. P. (2010). The investment behavior, decision factors and their effects toward investment performance in the Taiwan stock market. Journal of Global Business Management, 6(2), 1-12.

Lehr, U., \& Hegazi, A. (2017). The Socio-Economic Impacts of Renewable Energy and Energy Efficiency in Egypt Local Value and Employment. Retrieved from https://www.rcreee.org/sites/default/files/report-final_rcreee_website-_13-02.pdf

Lin, P. C., \& Huang, Y. H. (2012). The influence factors on choice behavior regarding green products based on the theory of consumption values. Journal of Cleaner Production, 22(1), 11-18. https://doi.org/10.1016/j.jclepro.2011.10.002

Mani, S., \& Dhingra, T. (2012). Diffusion of innovation model of consumer behaviour - Ideas to accelerate adoption of renewable energy sources by consumer communities in India. Renewable Energy, 39(1), 162-165. https://doi.org/10.1016/j.renene.2011.07.036

McCrone, A., Moslener, U., D’Estais, F., \& Grünig, C. (2017). Global Trends in Renewable Energy Investment 2017. Frankfurt School UNEP Collaborating Centre for Climate and Sustainable Energy Finance, 90. Retrieved from http://www.fs-unep-centre.org/

McDivitt, P. (2016). The Information Deficit Model is Dead. Now What? Evaluating New Strategies for Communicating Anthropogenic Climate Change in the Context of Contemporary. American Politics, Economy, and Culture, 111. Retrieved from http://scholar.colorado.edu/jour_gradetds

Ministry of Planning, Monitoring and Administrative Reform, I. (2017). Sustainable Development Strategy: Egypt's Vision 2030. Retrieved from http://sdsegypt2030.com/category/reports-en/page/3/?lang=en 
New \& Renewable Energy Authority. (2018). New \& Renewable Energy Authority.

Noppers, E. H., Keizer, K., Milovanovic, M., \& Steg, L. (2016). The importance of instrumental, symbolic, and environmental attributes for the adoption of smart energy systems. Energy Policy, 98, 12-18. https://doi.org/10.1016/j.enpol.2016.08.007

OECD/IEA and IRENA. (2017). Perspectives for the Energy Transition: Investment Needs for a Low-Carbon Energy System. International Energy Agency. Retrieved from http://www.irena.org/DocumentDownloads/Publications/Perspectives_for_the_Energy_Transi tion_2017.pdf

Osunmuyiwa, O., \& Kalfagianni, A. (2017). Transitions in unlikely places: Exploring the conditions for renewable energy adoption in Nigeria. Environmental Innovation and Societal Transitions, 22, 26-40. https://doi.org/10.1016/j.eist.2016.07.002

Papista, E., \& Krystallis, A. (2013). Investigating the Types of Value and Cost of Green Brands: Proposition of a Conceptual Framework. Journal of Business Ethics, 115(1), 75-92. https://doi.org/10.1007/s10551-012-1367-6

Park, E., \& Ohm, J. Y. (2014). Factors influencing the public intention to use renewable energy technologies in South Korea: Effects of the fukushima nuclear accident. Energy Policy, 65(April 2011), 198-211. https://doi.org/10.1016/j.enpol.2013.10.037

Peattie, K. (2010). Green Consumption: Behavior and Norms. Annual Review of Environment and Resources, 35(1), 195-228. https://doi.org/10.1146/annurev-environ-032609-094328

Regional Center for Renewable Energy and Energy Efficiency (RCREEE). (2013). Egypt: Net Metering Systems. Retrieved from http://www.rcreee.org/news/egypt-net-metering-systems

REN21 Renewable Energy Policy Network for 21st Century. (2017). Renewables 2017 Global Status Report. Retrieved from https://www.ren21.net/wp-content/uploads/2019/05/GSR2017_Full-Report_English.pdf

Reyes-Mercado, P. (2017). Adoption of renewable energy technologies in Mexico. International Journal of Energy Sector Management, 11(4), 626-649. https://doi.org/10.1108/IJESM-02-2017-0001

Rogers, E. M. (1995). Diffusion of innovations. Macmillian Publishing Co. https://doi.org/citeulike-article-id:126680

Rogers, E. M. (2003). Diffusion of innovations. New York: Free Press.

Sangroya, D., \& Nayak, J. K. (2017). Will Indian Industrial Energy Consumer Continue to Buy Green Energy? Organization \& Environment, 30(3), 253-274. https://doi.org/10.1177/1086026616634806

Saunders, M., Lewis, P., \& Thornhill, A. (2016). Research Methods for Business Students. Journal of Chemical Information and Modeling, (53). https://doi.org/10.1017/CBO9781107415324.004 
Sharaf, M. F. (2017). Energy consumption and economic growth in Egypt : A disaggregated causality analysis with structural breaks. Region et developpement, 46.

Sharma, R., \& Mishra, R. (2014). A Review of Evolution of Theories and Models of Technology Adoption. Managing, 6(2), 44. https://doi.org/10.9790/487X-1810063748

Sun, H., \& Su, Z. (2012). New Thoughts of Customer Value Study. Physics Procedia, 24(0902822), 1232-1237. https://doi.org/10.1016/j.phpro.2012.02.184

Sutherland, L. A., Peter, S., \& Zagata, L. (2015). Conceptualising multi-regime interactions: The role of the agriculture sector in renewable energy transitions. Research Policy, 44(8), 1543-1554. https://doi.org/10.1016/j.respol.2015.05.013

Tsagas, I. (2017). Egypt's PV net metering set to bear fruit. Retrieved from https://www.pv-magazine.com/2017/11/22/egypts-pv-net-metering-about-to-bear-fruit/

Uzialko, A. C. (2017). What Is B2B? Retrieved from https://www.businessnewsdaily.com/5000-what-is-b2b.html

Viardot, E. (2013). The role of cooperatives in overcoming the barriers to adoption of $\begin{array}{lllll}\text { renewable energy. } & \text { Energy } & \text { 756-764. }\end{array}$ https://doi.org/10.1016/j.enpol.2013.08.034

Wang, J., O'Donnell, J., \& Brandt, A. R. (2017). Potential solar energy use in the global petroleum sector. Energy, 118, 884-892. https://doi.org/10.1016/j.energy.2016.10.107

Westaby, J. D., Probst, T. M., \& Lee, B. C. (2010). Leadership decision-making: A behavioral reasoning theory analysis. Leadership Quarterly, 21(3), 481-495. https://doi.org/10.1016/j.leaqua.2010.03.011

World Bank. (2017). World Bank Development Policy Finance and Climate Change: Is the Bank providing the Right Incentives for Low-Carbon Development in Egypt? (January). Retrieved from https://bankinformationcenter.cdn.prismic.io/bankinformationcenter/190cde67-9281-496a-a6 be-ed888981de05_egypt-dpf-formatted-pub-1.6.17.pdf

Yun, S., \& Lee, J. (2015). Advancing societal readiness toward renewable energy system adoption with a socio-technical perspective. Technological Forecasting and Social Change, 95, 170-181. https://doi.org/10.1016/j.techfore.2015.01.016

Zahari, A. R., \& Esa, E. (2016). Motivation to Adopt Renewable Energy among Generation Y. Procedia Economics and Finance, 35(October 2015), 444-453. https://doi.org/10.1016/S2212-5671(16)00055-1

Zhao, Y., Noori, M., \& Tatari, O. (2017). Boosting the adoption and the reliability of renewable energy sources: Mitigating the large-scale wind power intermittency through vehicle to grid technology. Energy, 120, 608-618. https://doi.org/10.1016/j.energy.2016.11.112

Zikmund, W., Babin, B., Carr, J., \& Griffin, M. (2009). Business Research Methods (8th ed.). 
South-Western College Pub.

Zyadin, A., Puhakka, A., Ahponen, P., \& Pelkonen, P. (2014). Secondary school teachers' knowledge, perceptions, and attitudes toward renewable energy in Jordan. Renewable Energy, 62, 341-348. https://doi.org/10.1016/j.renene.2013.07.033

\section{Copyright Disclaimer}

Copyright for this article is retained by the author(s), with first publication rights granted to the journal.

This is an open-access article distributed under the terms and conditions of the Creative Commons Attribution license (http://creativecommons.org/licenses/by/3.0/). 